\title{
Food Safety: Does Your Kitchen Pass the Test?'1
}

Linda B. Bobroff and Jennifer Hillan²

Older adults are at increased risk for foodborne illness. To help reduce your risk, follow safe food handling practices at home. How does your kitchen measure up?

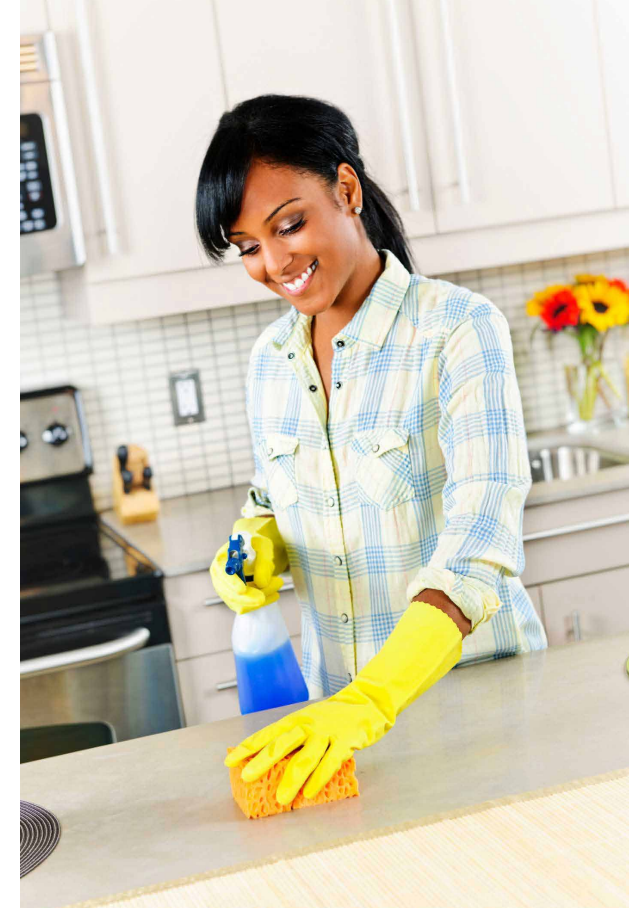

Figure 1. Credits: iStockphoto
1. The temperature of my refrigerator is:
a. $50^{\circ} \mathrm{F}\left(10^{\circ} \mathrm{C}\right)$.
b. $40^{\circ} \mathrm{F}\left(4^{\circ} \mathrm{C}\right)$ or less.
c. I've never measured it.

\section{When I have leftover cooked stew or other food with meat, chicken, or fish, I:}
a. Cool it to room temperature, then put in the refrigerator.

b. Put in the refrigerator immediately after the food was served.
c. Leave it at room temperature overnight and then refrigerate it.

\section{The last time my kitchen sink drain and disposal in my home were sanitized was:}
a. Within the last few days.
b. Several weeks ago.
c. I can't remember.

1. La versión español de este documento es Seguridad Alimentaria: ¿Su cocina pasa la prueba? (FCS8801-Span). This document is FCS8801, one of a series of the Department of Family, Youth and Community Sciences, UF/IFAS Extension. First published: April 2007. Latest revision: October 2013. Please visit the EDIS website at http://edis.ifas.ufl.edu.

2. Linda B. Bobroff, PhD, RD, LD/N, professor, and Jennifer Hillan, MSH, RD, LD/N, former ENAFS nutrition educator/trainer; Department of Family, Youth and Community Sciences, UF/IFAS Extension, Gainesville, FL 32611. 
4. I usually defrost meat, poultry, and fish products:
a. On the counter.
b. In the refrigerator.
c. In the microwave.

5. The last time cookie dough was made with raw eggs in my home:

a. I sampled some of it as soon as it was mixed.

b. It was refrigerated and then I sampled some of it.

c. I didn't sample it and waited until the cookies were baked.

6. If I use a cutting board for raw meat, poultry, or fish and then need it to chop another food, I:
a. Reuse it as is.
b. Wipe it with a damp cloth.
c. Wash it with soap and hot water.
d. Wash it with soap and hot water and then sanitize it.

7. I clean my kitchen counters and other surfaces that come in contact with food using:
a. Water.
b. Hot water and soap.
c. Hot water and soap, then a bleach solu- tion or a commercial sanitizing product.

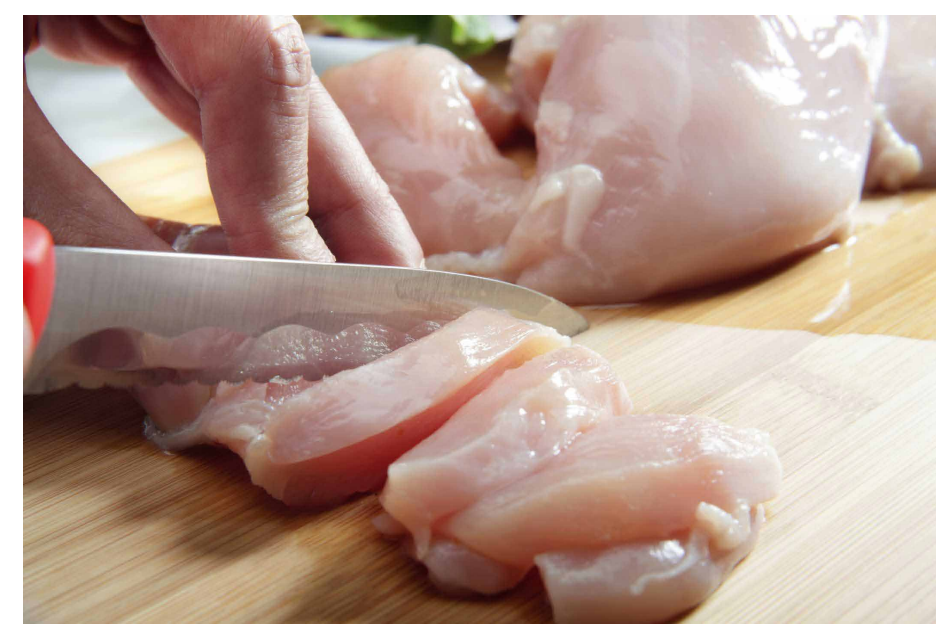

Figure 2. Credits: iStockphoto

\section{Answers}

1. The right answer is B. Refrigerators should stay at $40^{\circ} \mathrm{F}$ or less to slow the growth of most bacteria. Low temperatures won't kill the bacteria, but will keep them from multiplying. The fewer bacteria there are, the less likely you are to get sick. Freezing at $0^{\circ} \mathrm{F}$ or less stops bacterial growth, but it does not kill bacteria already present in food.

2. The right answer is B. Hot foods should be refrigerated as soon as possible within two hours after cooking. Don't eat food that has been standing out for more than two hours.

3. The right answer is A. The kitchen sink drain, disposal, and connecting pipe should be sanitized every few days. Make a solution of one teaspoon bleach in one quart (about one liter) of water and pour it down the drain.

4. The right answers are B and C. In addition to thawing food in the refrigerator, you also can thaw food on the counter in clean, cold water that is changed every 30 minutes. Do not thaw food on the counter or in the sink without cold water. Bacteria can multiply quickly at room temperature. Food thawed in the microwave must be 
cooked immediately; it cannot be put in the refrigerator and cooked at a later time.

5. The right answer is C. Eating foods made with raw or undercooked eggs can lead to foodborne illness. Be sure to cook foods made with raw eggs to at least $160^{\circ} \mathrm{F}$. Cook eggs until both the yolk and white are firm, not runny.

6. The right answer is D. Never let raw meat, poultry, or fish (or their juices) come in contact with other foods. Washing with a damp cloth will not remove bacteria. Washing with soap and water might not do the job either. After washing, you can sanitize cutting boards in a solution of one teaspoon bleach in one quart (about one liter) of water. You also can sanitize them by running them through the dishwasher.

7. The right answers are B or C. Hot soapy water will clean surfaces, but bleach or commercial kitchen cleaning products will sanitize them and kill some bacteria.

- FoodSafety.gov: This site is a portal to many government food safety websites. http:// www.foodsafety.gov/

- Foodsafety.gov - Clean: Wash hands and surfaces often: This site provides the basics of cleaning hands and surfaces. http://www. foodsafety.gov/keep/basics/clean/index.html

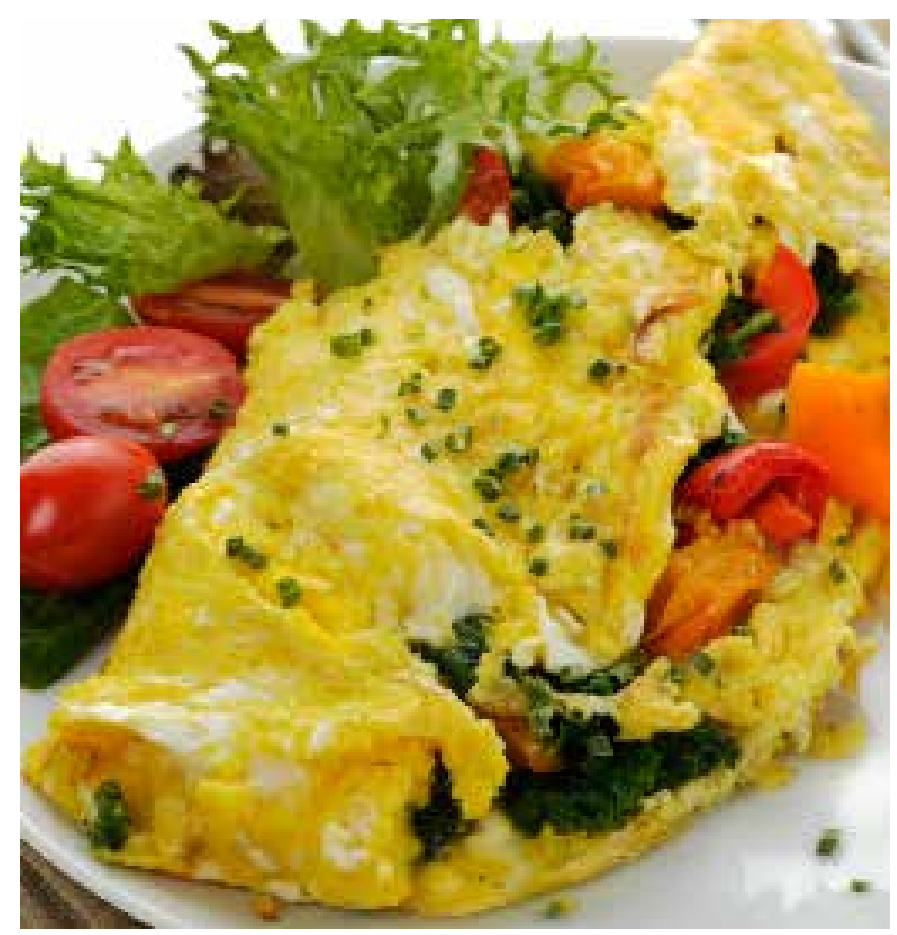

Figure 3. Credits: iStockphoto 